Dicle Tıp Dergisi / Dicle Medical Journal (2017) 44 (4) : 339-343

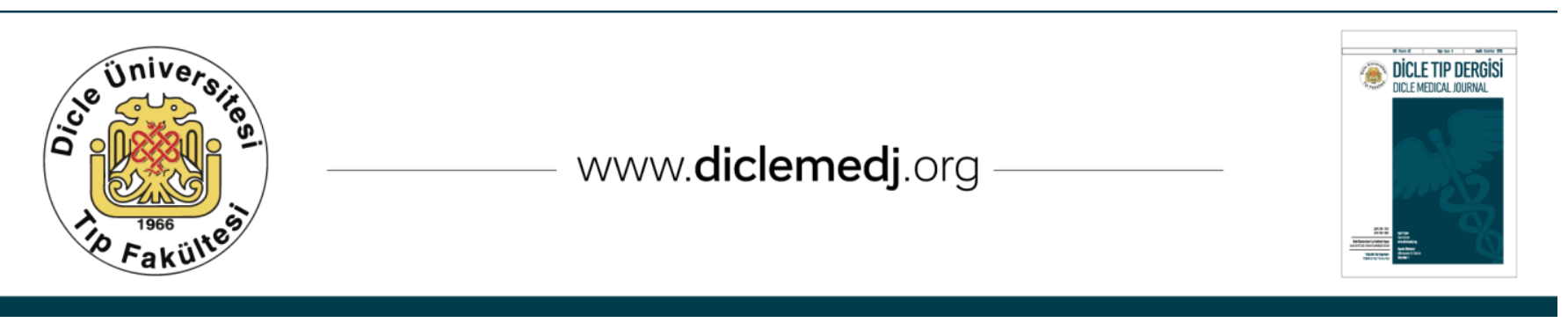

Özgün Araștırma / Original Article

\title{
Çoklu Primer Tümörler-Tek Merkez Deneyimi
}

\author{
Gökşen İnanç İmamoğlu1, Tülay Eren², Süleyman Şahin'3, Doğan Yazılıtaş4, Mustafa \\ Altınbaş ${ }^{5}$, Ramazan Esen ${ }^{6}$, Ebru Çılbır ${ }^{7}$, Fatih Karataş8, Özgür Ömer Yıldız ${ }^{9}$, Pelin Gümüşș
}

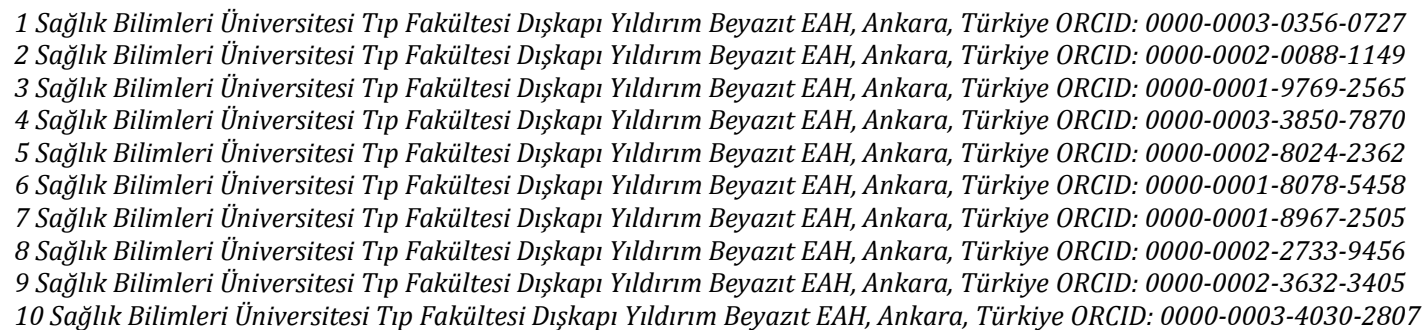

Geliş: 31.05.2017, Revizyon: 25.10.2017, Kabul Tarihi: 13.11.2017

\section{Özet}

Amaç: Onkolojik hastalıkların erken tanı ve tedavisinde yeni gelişmeler hayatta kalma oranlarının artmasına neden olsa da, artmış sağ kalım oranlarına bağlı olarak gelișen uzun takipler sırasında ikinci primer maligniteler ortaya çıkabilmektedir. İkincil primer tümörlerin gelişimi için birçok faktör vardır. En önemlisi, yaşlı hastaların uzun vadede kanserojenlere maruz kalma olasılıkları daha yüksektir. Çoklu primer tümörler, genellikle iki malignite tanısı arasındaki zaman çizelgesine bağlı olarak metakron veya senkron olarak görülür. Senkron hastalıklar sıklıkla benzer karsinojenlere maruz kalma sonucu oluşsa da, metakron olanlar daha çok primer tümörün tedavisine bağlı advers etkilerle ilișkili olabilir. Bu tek merkezli çalıșma, Ocak 2007 ile Aralık 2016 arasında multipl primer tümörlü hastaların klinikopatolojik özelliklerini araştırmayı amaçladı ve bunlardan 20'si senkron, 36'sı metakron olarak toplam 56 hasta dahil edildi. En yaygın kanser çiftlerinin erkeklerde kolon-akciğer ve prostat-mesane, kadınlarda meme-kolon ve meme-tiroid olduğu tespit edilmiştir.

Yöntemler: Ocak 2007 ile Aralık 2017 tarihleri arasında merkezimizde takip edilen ÇPT’ lü hastaların dosyaları retrospektif olarak incelendi, 56 hastada multiple primer tümör olduğu tespit edildi. Hastaların cinsiyetler, yaşları tespit edildi. Tümörün hangi organlarda oluştuğu, ne zaman geliștiği, bulunabilen etyolojik veriler, sağ kalım oranları araştırıldı. Tüm istatistiksel analizler Package for Social Sciences (SPSS v 15.0, SPSS Inc., Chicago, IL, USA) ile yapıldı.

Sonuç: Senkron hastalıklar genellikle benzer kanserojenlere maruz kalmanın bir sonucu olarak ortaya çlkarken, metakronöz hastalıkların primer tümörlerin tedavisinin yan etkileri ile ilișkili olması muhtemeldir

Anahtar kelimeler: Multipl primer tümör, senkron, metakron

DOI: $10.5798 /$ dicletip.362337

Yazışma Adresi / Correspondence: Gökşen İnanç İmamoğlu, Sağlık Bilimleri Üniversitesi Tıp Fakültesi Dışkapı Yıldırım Beyazıt EAH, Ankara, Türkiye e-mail: gokseninanc@hotmail.com 


\title{
Multiple Primary Tumors-Single Center Study
}

\begin{abstract}
Objective: Although new advances in early diagnosis and treatments of oncologic diseases have resulted in improved survival rates, second primary malignancies may occur as a result of prolonged follow-up durations related to increased survival rates. There are many factors for the development of secondary primary tumors. Most importantly, elderly patients are more likely to be exposed to carcinogens in long term. Multiple primary tumors are usually seen as either metachronus or synchronous, depending on the timeline between the diagnosis of two malignancies. While synchronous diseases often occur as a result of exposure to the similar carcinogens, metachronous diseases are likely to be associated with adverse effects of the treatment of primary tumors. This single-center study aimed to investigate the clinicopathological features of patients with multiple primary tumors between January 2007 and December 2016, including a total of 56 patients, 20 of whom were synchronous and 36 were metachronous. The most common cancer pairs have been found to be colon-lung and prostate-bladder in men and breast-thyroid, and breast-colon in women.

Method: Between January 2007 and December 2017, the files of our patients with multiple primary tumors (MPT) were reviewed retrospectively and it was determined that 56 patients had multiple primary tumors. Gender and age of the patients were determined. In which organs the tumor developed, when it developed, the etiologic findings that could be found, survival rates were investigated. All statistical analyzes were performed with Package for Social Sciences (SPSS v 15.0, SPSS Inc., Chicago, IL, USA).
\end{abstract}

Result: Synchronous diseases are often seen as a consequence of exposure to similar carcinogens, while metachronous diseases are likely to be associated with side effects of treatment of primary tumors.

Keywords: multiple primary tumors, synchronous, metachronous

\section{GíRIŞ}

Onkolojik tanı ve tedavilerdeki gelişmeler düzelmiş sağkalım ve hastalığın remisyonu ile sonuçlanmaktayken bir yandan da, artmış sağ kalım oranlarına bağlı uzamış takip süresi içerisinde sekonder primer malignitelerin gelişmesi olasılığı da artmaktadır. Çoklu primer tümörler (ÇPT), aynı hastada eş ya da farklı zamanlarda, patolojik olarak tanımlanmış ve birbirinden farklı gelişen tümörlerdir. ÇPT için günümüzde Warren ve Gates tarafindan tanımlanan bir terminoloji mevcuttur ${ }^{1}$. $\mathrm{Bu}$ tanıma göre; her bir tümörün kendisine ait klinik prezantasyonu olmalı, ayrı ayrı gelişmeli, ve diğer hastalığın metastazı olmamalıdır. Tanı zamanları aynı anda (senkron) olabileceği gibi farklı zamanlarda da olabilir (metakron). Senkron tümörler, primer tümör tanısından 6 ay içinde görülen tümör olarak tanımlanırken; metakron tümörler, primer tümör tanısından 6 aydan sonra ortaya çıkan tümörler olarak tanımlanmaktadır².
Senkron tümörler de etyoloji genellikle aynı kanserojen maddelere maruziyet olup, metakron tümörlerde ise primer tümörün tedavisinin uzun dönem komplikasyonları olarak nitelendirilebilir. Kanser nedeniyle kemoterapi veya radyoterapi uygulanan hastalarda primer hastalıkta kür sağlansa bile, düzenli takip ikincil tümörün erken tanısını sağlayabilmektedir ${ }^{3-6}$.

$\mathrm{Bu}$ makalenin amacı ÇPT’li hastalarda senkron ve metakron rastlanan ikinci ve/veya üçüncü tümörün birinci tümörle etyolojik ilişkisini araştırmak, ve buna göre klinisyenlerin nasıl önlemler alabileceği konusunda öneriler getirmektir.

\section{YÖNTEMLER}

Ocak 2007 ile Aralı 2016 tarihleri arasında merkezimizde takip edilen 4120 hastanın dosyası incelendi. Çalışmaya, farklı organlarda aynı anda (senkron) tanı konulan veya farklı zamanlarda (metakron) başka bir organda tanı 
konulan primer tümörleri olan hastalar alındı. Metastaz veya komşu organa invazyon düşünülen hastalar çalışma dışı bırakıldı. Toplam 56 hastada ÇPT olduğu tespit edildi. Hastaların cinsiyetleri, yaşları tespit edildi. Tümörün hangi organlarda oluştuğu, ne zaman geliştiği, bulunabilen etyolojik veriler, sağkalım oranları araştırıldı. Tüm istatistiksel analizler PackageforSocialSciences (SPSS v 15.0, SPSS Inc., Chicago, IL, USA) ile yapıldı.

\section{BULGULAR}

Demografik veriler olarak; çoklu primer tümör görülen 56 hastanın 18'i kadın, 38'i erkek hastaydı. Kadın hastaların yaş ortalaması 58, erkek hastaların yaş ortalaması 68 olarak bulundu. Her iki cins için ortalama yaş 63 olarak tespit edildi. Kadın/erkek oranı 2.1 olarak tespit edildi. Hastaların 20'sinde ikinci tümör senkron tümör olarak ortaya çıkarken diğer hastalarda metakron olarak tespit edildi ve ikinci primer tümörün görülme oranı $\% 1,35$, tanı süresi ise 63 ay olarak gözlendi.

Etyolojik faktörler açısından ikincil tümöre neden olabilecek en önemli özelliklerin sigara kullanımı ve aile öyküsü olduğu görüldü.

Kadınlarda en sık görülen tümör meme, ikinci en sik görülen tümör kolon kanseri olarak tespit edildi. Erkeklerde ise prostat ve akciğer kanseri en sık görülen kanserler olarak bulundu.

\section{TARTIŞMA}

Günümüzde onkolojik hasta profilleri çok değişmiştir. Artık cerrahi evrede yakalanabilen hasta sayısı giderek artmakta, son yıllarda organ koruyucu cerrahi prensibi ile hayat kalitesi ön plana çıkmaktadır. Bunun yanısıra metastatik süreçteki hastalarda geliştirilen yeni tedavilerle hastanın sağ kalım süresi uzamaktadır. Ancak bu durum ikincil tümör kavramını daha da önemli hale getirmiştir? Primer tümörlü olgularda ikinci bir kanser gelişme riski, sağlıklı bireylerle göre 1,29 kat daha yüksek bulunmuştur8. Bizim hastalarımızda bu oran \%1,35 dir.

İkincil tümörün gelişmesinde birçok etken vardir. Bunlardan en önemlisi hastaların ileri yaşta olmaları nedeniyle kanserojenlerle daha fazla ve daha uzun süre karşı karşıya kalmış olmasıdır. Bizim hastalarımızda yaș ortalaması 63 olarak bulunmuştur.

ÇPT tanılı hastalarda erkek/kadın oranı çeşitli yayınlarda 0,9 ile 3,5 arasında değişmektedir. Cinsiyet açısından bakıldığında bizim hastalarımızda erkek/kadın oranının 2.1 olduğu ve bu durumun literatürle de uyumlu olduğu görülmektedir? .

Hastalı senkron ortaya çıkabildiği gibi genellikle metakron olarak görülmektedir. Senkron hastalıklar genellikle benzer kanserojenlere maruziyet sonucu oluşurken. Metakron hastalıklarda birincil tümöre uygulanan tedavilerin olumsuz etkisinden bahsedilebilir. Bizim hastalarımızın 20'si senkron hastalık iken, 36'sı metakron hastalık olarak ortaya çlkmıştır?

Etyolojik faktörler primer tümörü oluşturan nedenler olabileceği gibi ilk tümöre uygulanan tedavilere de bağlı olabilir9 . Bilindiği gibi dünyada ve Türkiye'de erkeklerde en sik görülen kanser prostat ve akciğer, kadınlarda da meme ve tiroid kanseridir. Ylllı kanser istatistiklerinin yayınlandığı SEER (survaillence, epidemiology, end results program) verilerine göre erkeklerdeki en sık tümör çiftleri (indeks tümör-ikinci tümör) prostat- solunum sistemi kanserleri, ikinci olarak prostat-kolon kanseridir. Kadınlarda ilk iki sırayı meme kanseri-meme kanseri, ikinci olarak da meme kanseri- kolon kanseri çiftleri almıștır ${ }^{10}$. Bizim hastalarımızda erkeklerde kolon-akciğer, prostat-mesane çiftleri, kadınlarda ise meme-tiroid, meme-kolon çiftlerinin ön planda olduğu görülmektedir (Tablo1-2). 
İmamoğlu G.İ., Eren T., Şahin S., Yazılıtaş D., Altınbaş M., Esen R., Çılbır E., Karataş F., Yıldız Ö.ö., Gümüş̧ P.

Tablo 1. Kadın hastalarda tümörlerin organlara göre dağılımı.

\begin{tabular}{lll}
\hline Kadın & Tümör & Sayı-Oran \\
\hline En sık 1. tümör & Meme & $6 \% 33,3$ \\
En sık 2. tümör & Kolon & $5 \% 27,7$ \\
En sık 1. tümör çifti & meme-kolon & $5 \% 27,7$ \\
En sık 2. tümör çifti & meme-tiroid & $4 \% 22,2$ \\
\hline
\end{tabular}

Tablo 2. Erkek hastalarda tümörlerin organlara göre dağllımı

\begin{tabular}{lll}
\hline Erkek & Tümör & Sayı-Oran \\
\hline En sık 1. tümör & Prostat & $8 \% 21$ \\
En sık 2. tümör & Akciğer & $8 \% 21$ \\
En sık 1. tümör çifti & Prostat-Mesane & $6 \% 15,7$ \\
En sık 2. tümör çifti & Akciğer-Kolon & $5 \% 13,1$ \\
\hline
\end{tabular}

Çoklu primer kanserlerde, birinci kanser gelişim bölgesinde ikincil kanserlerin gelişim olasılığı yüksektir. Bunun nedeni primer kanser bölgesindeki aynı karsinojenik ajanlara maruziyet veya genetik değişiklikler sonucunda farklı organlarda kanser gelişimidir ${ }^{11}$. Bizim çalışmamızda kadınlarda meme-tiroid, erkelerde de prostat-mesane kanserlerinin daha sık görülmesini bu teoriyle açıklayabilmemiz mümkündür.

Prognoz açısından bakıldığında çoklu primer kanser olgularında ve özellikle senkron tümörlerde daha kötü bir sağkalım süresi olduğu görülmektedir ${ }^{12}$.

Sonuç olarak, bütün bu bulgular kanser tedavisi yapılmakta hastaların uzun süre takip edilmelerinin önemi ortaya çıkmaktadır. Yapılan tedavilerin uzun dönemde yan etkiler nedeniyle yeni kanser oluşumuna neden olabileceği daima hatırlanmalıdır. Kanser takip kılavuzlarında geçen takip süreleri primer tümör için önemlidir ancak metakron tümör riski nedeniyle bu takipler hayat boyu devam ettrilmesi gerekir. Bunun yanı hastaların kanserden koruyucu önlemler konusunda bilgilendirilmesi, takiplerde gereksiz tetkiklerden kaçınılması, ailevi risk taşıyan hastalara daha sık tarama testlerinin yapılması ve yaşam tarzı değişiklikleri ile hastanın hayat kalitesinin artırılması yoluna gidilmelidir.

Çıkar Çatışması Beyanı: Yazarlar çıkar çatışması olmadığını bildirmişlerdir.

Finansal Destek: Bu çalışma her hangi bir fon tarafından desteklenmemiştir.

Declaration of ConflictingInterests: The authors declare that they have no conflict of interest.

Financial Disclosure: No financial support was received.

\section{KAYNAKLAR}

1. Warren S, Gates O. Multiple primarymalignant tumors: A survey of the literature and a statistical study. Am J Cancer 1932;16:1358-414.

2. Suzuki T, Takahashi H, Yao K, et al. Multiple primary malignancies in the head and neck: a clinical review of 121 patients. Acta Otolayngol Suppl 2002;547:88-92.

3. Hemminki K, Boffetta P. Multiple primary cancers as clues to environmental and heritable causes of cancer and mechanisms of carcinogenesis. IARC Sci Publ 2004;157:289-97.

4. Carey TE. Field cancerization: are multiple primary cancers monoclonal or polyclonal? Ann Med 1996;28:183-8.

5. Dong C, Hemminki K. Multiple primary cancers of the colon, breast and skin (melanoma) as models for polygenic cancers. Int J Cancer 2001;92:883-7.

6. Miki Y, Swensen J, Shattuck-Eidens D, et al. A strong candidate for the breast and ovarian cancer susceptibility gene BRCA1. Science 1994;266:66-71.

7. Ries LAG, Harkins D, Krapcho M, Mariotto A, Miller BA, Feuer EJ, et al. SEER Cancer Statistics Review, 19752003, National Cancer Institute. Bethesda, MD, http://seer.cancer.gov/csr/1975_2003.

8. Shikhani AH, Matonoski GM, Jones MM, Kashima HK, Johns ME. Multipleprimary malignandes in head and neckcancer. Arch Otolaryngol Head Neck Surg1986;112:1172-5.

9. Demandante CG, Troyer DA, Miles TP. Multipleprimary malignant neoplasms: case reportand a comprehensive review of the literature. Am J Clin Oncol 2003;26:79-83. 
10. Hayat MJ, Howlader N, Reichman ME, Edwards BK. Cancer statistics, trends, and multiple primary cancer analyses from the Surveillance, Epidemiology, and End Results (SEER) Program. Oncologist 2007;12:20-37.

11. Fraumeni JF Jr.,Curtis RE, Edwards BK et al.Introduction. In: Curtis RE, Freedman DM, Ron E etal.,eds. New malignancies among cancer survivors: SEER Cancer Registries, 1973-2000. Bethesda, MD:National Cancer Institute, 2006.
12. Gokyer A, Kostek O, Hacioglu MB, Erdogan B, Kodaz $\mathrm{H}$, Tutkmen E, et al. Clinical features of the patient with multiple primary tumors: Single center experience. North Clin İstanb 2017;10: 43-51. 